\title{
Correction to: Preparation and properties of a coniferin enantiomer
}

Haruka Maeda ${ }^{1}$, Taku Tsuyama² ${ }^{2}$ Keiji Takabe ${ }^{1}$, Hiroshi Kamitakahara ${ }^{1}$ and Toshiyuki Takano ${ }^{1 *}$ (i)

\section{Correction to: J Wood Sci (2019) 65:34}

https://doi.org/10.1186/s10086-019-1813-5

In the original publication of the article, the letter " $\mathrm{"} \mathrm{in}$ the section headings was published incorrectly as "l". It should appear as " $\mathrm{"} \mathrm{throughout} \mathrm{the} \mathrm{article} \mathrm{[1].}$

In the "Results and discussion" section, the second sentence in the first paragraph was published incorrectly as "Compound 1D was also prepared.........compound 6L". It should read as "Compound 1D was also prepared. compound 1L".

The caption of Fig. 3 was published incorrectly as ${ }^{~} 1 \mathrm{H}$ NMR spectra of compounds $1 \mathrm{~L}(\mathbf{a})$ and $\mathbf{1 D}(\mathbf{b}) ;{ }^{13} \mathrm{C}$ NMR spectra of compounds $1 \mathbf{L}\left(\mathbf{a}^{\prime}\right)$ and $\mathbf{1 D}\left(\mathbf{b}^{\prime}\right)$ ". The corrected Fig. 3 caption should read as "1H NMR spectra of compounds 1L (a) and 1D (b); ${ }^{13} \mathrm{C}$ NMR spectra of compounds $1 \mathbf{L}\left(\mathbf{a}^{\prime}\right)$ and $1 \mathbf{D}\left(\mathbf{b}^{\prime}\right)$ "'.

\begin{abstract}
Author details
${ }^{1}$ Division of Forest and Biomaterials Science, Graduate School of Agriculture, Kyoto University, Kitashirakawa oiwake-cho, Sakyo-ku, Kyoto 606-8502, Japan. 2 Department of Forest and Environmental Sciences, Faculty of Agriculture, University of Miyazaki, 1-1 Gakuenkibanadai-nishi, Miyazaki 889-2192, Japan.
\end{abstract}

Published online: 07 March 2020

\section{Reference}

1. Maeda H, Tsuyama T, Takabe K, Kamitakahara H, Takano T (2019) Preparation and properties of a coniferin enantiomer. J Wood Sci 65:34. https:// doi.org/10.1186/s10086-019-1813-5

\section{Publisher's Note}

Springer Nature remains neutral with regard to jurisdictional claims in published maps and institutional affiliations.

\footnotetext{
*Correspondence: takatmys@kais.kyoto-u.ac.jp

1 Division of Forest and Biomaterials Science, Graduate School

of Agriculture, Kyoto University, Kitashirakawa oiwake-cho, Sakyo-ku,

Kyoto 606-8502, Japan

Full list of author information is available at the end of the article
}

\section{Springer Open}

c The Author(s) 2020. This article is licensed under a Creative Commons Attribution 4.0 International License, which permits use, sharing, adaptation, distribution and reproduction in any medium or format, as long as you give appropriate credit to the original author(s) and the source, provide a link to the Creative Commons licence, and indicate if changes were made. The images or other third party material in this article are included in the article's Creative Commons licence, unless indicated otherwise in a credit line to the material. If material is not included in the article's Creative Commons licence and your intended use is not permitted by statutory regulation or exceeds the permitted use, you will need to obtain permission directly from the copyright holder. To view a copy of this licence, visit http://creativecommons.org/licenses/by/4.0/ 